\title{
Effects of a cold wave on an Amazonian avifauna in the upper Paraguay drainage, Western Mato Grosso, and suggestions on Oscine-Suboscine relationships
}

\author{
Edwin O'Neill Willis (")
}

\begin{abstract}
The avifauna of the forested upper reaches of the Sopotuba River, in the upper Paraguay drainage just south of the Serra dos Parecis, proved a mixture of central-Amazonian birds from just east of the Madeira River and of birds of dry forests (Xingú-Tapajóz) or lower Andean forests peripheral to the southern Amazonian region. A cold wave that passed during the study period caused a major drop in insect activity and in the activity of insect-eating birds and hummingbirds. Fruit-eating birds and "omnivores" (insect and fruit eaters) became relatively conspicuous. It is suggested that occasional "disasters" of the type of a cold wave inhibit specialized insectivores at this and other margins of Amazonian forests, and encourage higher percentages of omnivores. The previously noted tendency for oscines to replace suboscines at various types of neotropical forest margins is reinterpreted as primarily due to declines of furnarioid suboscines (mostly forest-living insectivores) and their replacement by omnivorous tyrannoid suboscines and by omnivorous oscines. The conventional theory that furnarioid suboscines are primitive and that they and other neotropical suboscines are being pushed into forests by recently immigrating oscines leads to two ecological anomalies: virtual absence of omnivorous passerines in the carly Cenozoic and absence of seed-eating passerines for much of the late Cenozoic. As alternate theory, that of separation of forest-edge suboscines by continental dritr followed by evolution of forest-dwelling furnarioid suboscines in the New World, with open-country oscines either separated by the drift or entering South America early in the Cenozoic, removes both anomalies.
\end{abstract}

In western Mato Grosso, a narrow peninsula of Amazonian forest follows the Guaporé River southward and eastward on the south side of the Serra dos Parecís, a campo or cerrado-covered plateau of some 500 meters'elevation. This forest peninsula once reached east into the drainage of the upper Paraguay River, at least to the town of Barra

(*) - Universidade Estadual de Campinas, SP. de Bugres. East of Barra de Bugres, the remaining vegetation is mostly dry forest grading into cerrado and pantanal. From Barra de Bugres westward, the forest is rapidly being cut.

Since birds of the Paraguay-drained eastern part of this forest had only been studied briefly by Natterer (in Pelzeln, 1867) and by Naumburg (1930) and coworkers, I welcomed an opportunity to look at birds there on an expedition of the Zoology Department of the Universidade Estadual de Campinas (UNICAMP) from 11 to 21 July, 1975. During our visit, a major cold wave or friagem swept north, bringing frost and snow to southern Brazil and ending as floods in northeastern Brasil. This offered an opportunity to look at the effects of a friagem at the southern margin of the Amazonian forest, and contrast observations with previously reported minor effects of cold waves well to the north (such as Bates, 1962: 330).

Here I give the species observed, and by means of daily counts of individuals and species eating various foods illustrate certain effects of the cold wave which, magnified in regions of greater altitude or farther south, could lead to such oft-reported avifaunal phenomena as replacement of suboscine by oscine Passeriformes at various kinds of borders of neotropical forests (Slud, 1960; Novaes, 1973).

\section{LOCALES AND CHRONOLOGY}

Few patches of forest remain along the road from Barra de Bugres $70 \mathrm{~km}$ west to the plateau town of Tangará da Serra. July 11 and 12 , the UNICAMP expedition visited forest remnants at about $150 \mathrm{~m}$ elevation and $30 \mathrm{~km}$ 
W of Barra de Bugres, plus continuous zones of seasonally flooded woodlands (várzea) along the small Branco River just south. July 13 and 14, after crossing a zone of dry woodlands and of cerrado on a spur ("Serra dos Cinquenta") of the Serra at and east of Tangará, we visited large patches of recently logged forest on the east side of the Sopotuba River (spelled "Sepotuba" and other variants by Pelzeln, 1867, and Naumburg, 1930) some $20 \mathrm{~km}$ W of Tangará.

July 15 to 17 we worked in sandier but extensive low woodlands some 30 to $40 \mathrm{~km}$ NW of Tangará and beyond the Sopotuba River. on the road from the Maracanã River to the "Fazenda do Português". Near the sandstone cliffs of the Serra, some areas are very sandy; for instance, one area of low scrub and scrub-woodland supported singing Rhytipterna immunda, a bird that near Manaus occurs in structurally similar sandy "campinas" (Lisbôa, 1975 ) and in Surinam in sand-ridge scrubland (Haverschmidt, 1975).

July 18 we investigated forest remnants $20 \mathrm{~km}$ SW of Tangará, near Fazenda Tapirapoã on the Sopotuba River. July $19-20$ we visited tall forests being cleared on Fazenda Arapitanga, about $30 \mathrm{~km} \mathrm{NE}$ of town on the Sopotubinho River. Most of the forests on these days, as on July 13-14, were on deep clay riverin soils and at $200-350 \mathrm{~m}$ elevation. July 21 we returned to the wooded patches $30 \mathrm{~km}$ W of Barra de Bugres.

\section{THE "FRIAGEM"}

July is the middle of the long dry winter in western Mato Grosso, Skies are normally cloudless, night temperatures cool, and day temperatures high. July $11-16$ temperatures became steadily warmer, reaching about $35^{\circ} \mathrm{C}$ at midday. At 15:00 on July 16, undulating dark clouds suddenly covered the southern sky and approached rapidly. At 16:00 wave after wave of Whiteeyed Parakeets (Aratinga leucophthalma) came high over, headed northward with constant gabble. I estimated that some 500 birds crossed within my sight from a narrow road through low forest. The clouds were less black as they came overhead in waves of dark and light gray, and instead of rain there was a steady rush of wind twisting the treetops. Temperatures dropped very slowly, even with the constant wind and with the undulating canopy of clouds racing northward. The trees near our camp groaned and there was a !ight drizzle much of the night, but the morning of the 17th was only moderately cool. At dawn, birds were normally noisy. However, the wind and clouds continued to hurry north, and temperatures barely rose beyond the low night level. Not one of the stingless bees and "African" bees, a constant nuisance in the sandy forest the preceding two days, appeared the whole day. Two colonies of army ants (Eciton burchelli) under observation failed to move the whole day, and individuals responded as if in slow motion even when disturbed. Even when the sun appeared about 13:00 hardly a butterfly moved along the road.

Clear skies continued after the front passed. By 16:00 temperatures were dropping rapidly. Night temperatures apparently reached below $3^{\circ} \mathrm{C}$ (temperature recorded in Cuiabá, at $150 \mathrm{~m}$ elevation), with light frost reported from the tips of leaves of coffee sprouts. The following morning was very cold, and forest birds silent. Gradually temperatures rose, but the day was still cold and insect-free.

July 19 and 20 day temperatures in the forest continued decidedly cool, much like those of a subtropical forest. A colony of army ants started swarming only just before noon on July 19, and the ants moved $6 \mathrm{~m}$ per hour rather than the usual 15 or so. July 20 the ants started about $09: 30$, and traveled about $10 \mathrm{~m}$ per hour. Butterfly and other insect activity seemed fairly high after noon on July 19 and after about midmorning on July 20 , but on the second day many butterflies were dying on the road.

THE AVIFAUNA, AND EFFECTS OF THE COLN WAVE

In the Appendix, species of birds observed are listed as well as numbers of individuals seen or heard in the indicated numbers of hours afield each day. A bird marked (?) is probably the species indicated, but could be 
close relative of it. The list follows Meyer de Schauensee (1970) even when later revisers or my own observations suggest a different taxonomy. Types of food are indicated for each family as follows: A, nectar and insect feeders; B, fruit or seed eaters; C, fruit and insect eaters; $D$, insectivores; $E$, carnivores other than insectivores. When a species differs from the majority of its family, the fond type is indicated after its name. Food types are from Haverschmidt (1968) and other authors, plus my own observations.

Table 1 totals counts of species and individuals of food types $A$ through $D$ for the days July 13-20, when we were working in fairly comparable areas close to Tangará da Serra. More detailed analyses, such as timed census runs in the same area, were not possible both because I did not know that a cold wave would pass and because we had to move about for the research of others in the group.

Table 1 indicates that on the two coldest days, July 17 and 18, the number of species observed was about one-half of normal and the number of individuals about one-third of normal. (The waves of parakeets raised the total unduly on July 16; probably 50 or less of the 500 would have been seen on an crdinary day, and 50 is the number used here for certain comparisons). Specifically, after the normal!y noisy dawn of July 17 (indicating that cold itself did not dampen calling and song until the birds had to look for food), forest birds became silent and hard to locate. Parrots and pigeons continued relatively noisy, but even they were rather silent July 18 . On July 19 and 20 , the amount of calling increased to levels possibly but not clearly below the usual forest level.
Table 2 separates the birds by food types A through D. Some of the "insectivores" may also eat some fruits, as diets of most species are not well known.

Hummingbirds (Type A) most strongly showed effects of the cold wave. None was seen on the 17th, one on the 18th, and one (a Heliomaster turcifer very weak of flight in a sunlit treetop) on the 19th. Fair numbers were active at well-lighted treetop sites and in some areas of undergrowth on the 20th. Hummingbirds are known to enter torpor at night and during cold periods, and it is possibie that some individuals did so during much of the cold wave.

Fruit-eating birds remained active and fairly conspicuous decreasing in absolute numbers seen but rising slightly in percentage of the avifauna, from the normal 10 or 15 percent of species to about 20 percent on the 18 th, and from the normal 25 percent of the individuals seen to 40 percent on that day and the next.

"Omnivorous" birds, eating fruit and insects, were less frequently observed during the cold wave but remained at about the usual percentages of the avifauna -40 percent of the species and slightly over 35 percent of the individuals. These species continued active and fairly conspicuous, but flocked to fruiting trees instead of hunting insects (except in sunlit areas at the warmest hours of afternoon, when they stayed close to the fruit trees in their hunts).

Insectivorous birds were quiet and inconspicuous, though the few seen seemed to forage actively. Percentages decreased from a normal species percentage of 40 to 31 on the 18th, and from a normal 35 or so percent

TABLE 1

Species and Individuals of Forest Birds

\begin{tabular}{|c|c|c|c|c|c|c|c|c|c|c|c|}
\hline & $\begin{array}{l}\text { July } \\
11\end{array}$ & 12 & 13 & 14 & 15 & 16 & 17 & 18 & 19 & 20 & 21 \\
\hline species & 61 & 103 & 91 & 106 & 114 & 92 & 50 & 42 & 94 & 119 & 87 \\
\hline Indivtduals & 191 & 560 & 409 & 552 & 526 & $859^{a}$ & 157 & 161 & 490 & 746 & 461 \\
\hline
\end{tabular}

a. 409 if same 450 "extra" parakeets are excluded (see text). 
of individuals to 22 percent on that day. Birds that follow army ants disappeared completely July 17-18, and did not even apear near inactive bivouacs during my visits. Mixed-species flocks were smaller than usual, and several were at sunny areas overgrown with vines at edges of the forest. Torpor or major mortality seems unlikely; probably the birds were simply less conspicuous.

\section{AFFINITIES OF THE TANGARÁ DE SERRA FAUNA}

The analyzable avifauna (species other than widely distributed ones without distinctive subspecies) of the forests near Tangará da Serra is most closely related to the avifauna of forests east of the rio Madeira, but shows some elements from other regions, such as lower Andean forests and dry forests south and east of the Tapajóz River. The relationships are most clearly shown by birds that regularly follow army ants, for most occur only or mainly east of the Madeira:

Rhegmatorhina hoffmannsi, an ant-following species of the east bank of the Madeira, is replaced by related species west of the Madeira and on both sides of the lower Tapajóz (Willis, 1969). Dendrocolaptes hoffmannsi ranges from the Madeira to the Xingú, and is replaced by different subspecies of the related
D. picumnus to north, south, northeast, and west. (Local distribution of birds of this group is complex. For instance, Naumburg, 1930 , reports that near Tangará the related $D$. platyrostris wedges in from the east, presumably in gallery woodlands on the open planalto of the Serra, and D. picumnus pallescens wedges up from the south, in pantanal or semiopen woodlands). Hylexetastes perroti uniformis is widespread between the Madeira and the Xingú, but is replaced by $H$. stresemanni westward. The Dendrocincla fuliginosa observed here were probably of the subspecies atrothorax from between the Madeira and Tapajóz Rivers, for they were streaked and had the unusual call characteristic of this subspecies; this subspecies is already known from the Guaporé River (I do not, however, know D. f. trumaii from the upper Tapajóz-Xingú region, and suspect it may not be distinguishable in the field). The Dendrocincla merula seemed of the subspecies olivascens from the Madeira to the Tapajóz, not of bartletti or remota from west of the Madeira nor of castanoptera from east of the Tapajóz. Phlegopsis nigromaculata seemed of the large-spotted and white-sided form bowmani, which ranges from the Madeira to the Xingú. These species or distinctive subspecies suggest entrance of the avifauna east

TABLE 2

Percentages of Species and Individuals of Forest Birds by Food Type

\begin{tabular}{|c|c|c|c|c|c|c|c|c|}
\hline & July & & & & & & & \\
\hline & 13 & 14 & 15 & 16 & 17 & 18 & 19 & 20 \\
\hline \multicolumn{9}{|l|}{ SPECIES \% } \\
\hline Hummingbirds & 2 & 5 & 8 & 4 & 0 & 2 & 1 & 3 \\
\hline Frugivores & 16 & 14 & 12 & 10 & 14 & 21 & 14 & 11 \\
\hline Fruit/Insects & 40 & 39 & 39 & 42 & 40 & 43 & 38 & 41 \\
\hline Insectivores & 39 & 42 & 39 & 39 & 40 & 31 & 45 & 43 \\
\hline Others & 3 & 0 & 3 & 4 & 6 & 2 & 2 & 2 \\
\hline \multicolumn{9}{|l|}{ INDIVIDUALS \% } \\
\hline Hummingbirds & 1 & 3 & 8 & $2(3)^{a}$ & 0 & 1 & 0 & 2 \\
\hline Frugivores & 25 & 28 & 22 & $64(24)$ & 26 & 40 & 38 & 28 \\
\hline Fruit/Insects & 40 & 33 & 36 & $17(35)$ & 34 & 37 & 33 & 36 \\
\hline Insectivores & 34 & 36 & 33 & $17(36)$ & 38 & 22 & 29 & 34 \\
\hline Others & 1 & 0 & 1 & 0 (1) & 3 & 1 & 1 & 0 \\
\hline
\end{tabular}

a. When 450 "extra" parakeets excluded from total. 
of the Madeira, either up the Guaporé or across the Serra dos Parecís from the Gi-Paraná River (Machados) or western headwaters of the Tapajóz. Tangará da Serra marks the southwestern limit of the known ranges of most of these species, but many may possibly be found to circle the upper Guaporé into eastern. Santa Cruz, Bolivia. I did not see Dendrocolaptes concolor, an ant-following bird reported from the Madeira to the Xingú and replaced by subspecies of $D$. certhia to east ant west, but concolor has been reported from the upper Guaporé (Pelzeln, 1867) and probably occurs near Tangará.

In contrast to the above, Hylophylax poecilonota griseiventris of Tangará is a form that occurs both east and west of the Madeira. Pyriglena leuconota maura, which I encountered only in sandy low woodland near the Serra, is the southern representative of a species that crosses central Brazil in dry forests and extends northewestward in subtropical forests along the Andes.

Several other species or distinctive subspecies show the same pattern as that for most ant-following birds, being birds from east of the Madeira River: Selenidera maculirostris gouldii, Pteroglossus $i$. inscriptus, P. bitorquatus sturmii, and Pipra nattereri. Some species (like Pyriglena leuconota) descend along the lower Andes and are known to extend eastward in dry forests into this region or beyond, but are absent from west of the lower Madeira: Tinamus tao, Phaethornis hispidus, Aratinga weddellii, Nyctiphrynus ocellatus, Nystalus striolatus, Piculus leucolaemus, Drymophila devillei, Herpsilochmus rufimarginatus, Myrmeciza hemimelaena, Tangara cyanicollis, $T$. nigrocincta, and perhaps others.

Certain species of the region of Tangará da Serra seem species of the gallery woodlands and dry-forested belt extending from east of the Tapajóz River across into eastern Bolivia, even though the belt seems interrupted by such large areas of open vegetation as the top of the Serra dos Parecis. Ara maracana, Ara nobilis, Brachygalba lugubris, Captto dayi, Herpsilochmus longirostris, Neopelma pallescens, Odontorchilus cinereus, and possibly Hylophilus pectoralis are here re- corded at or near their southwestern limits in this belt, and do not occur on the Andes or in humid forests on the lower Madeira.

The analyzable avifauna of the forests near Tangará thus seems a mixture of species of humid Amazonian forests, entering primarily from the north along the east side of the Ma. deira, and southern species of upper tropical or dry forests fringing the central part of Amazonia. Many species widespread in humid central Amazonia seemed absent, at least in this brief survey: Tinamus guttatus, Tinamus major, Pionites leucogaster, Gypopsitta vulturina, Thamnomanes saturninus, etc. The vegetation is not the tall and complex forest of central Amazonia, but a forest of moderate (rarely low) height and moderately complex structure; and the climate is marked by a long dry "winter". Probably the mixture of central-Amazonian and peripheral-Amazonian forest birds is what one could expect from the subequatorial latitude (nearly $15^{\circ} \mathrm{S}$ ), climate and vegetation.

Studies of butterflies have also indicated a mixture of Peruvian-Bolivian (upper tropical), Xingú-Tapajóz (dry forest), and central Amazonian forms, but without strong restriction to Amazonian forms from east of the Madeira; the Madeira seems less important as a barrier for butterflies than for birds (Brown, 1972: 191 and pers. comm.). Butterflies show some endemic forms, suggesting to Brown a former forest "refuge" in the region during dry climatic periods, but the avifauna seems a mixture-as of recolonization after a dry epoch. Haffer $(1969,1974)$ does not indicate that the region was an important refuge or center of speciation for birds. It is possible, however, that further west along the Serra dos Parecís are better forests and better avifaunas-certainly the butterfly fauna is richer (K. S. Brown, pers. comm.).

\section{Discussion}

In the context of the "peripheral" (to the Amazonian "center") nature of this avifauna and forest, the observations of birds during the cold wave suggest some phenomena which, amplified even more peripherally by 
more frequent or stronger cold, might lead to replacement of suboscine Passeriform birds by oscines in those more peripheral zones. Insectivorous birds became less conspicuous during the cold wave, while frugivorous and omnivorous ones remained relatively conspicuous. This suggests that insectivorous birds had difficulties finding prey, and had no time or extra energy for singing or the like; and that frugivores and omnivores moved to fruiting trees where food remained available despite the cold. The decreased insect activity was obvious even to an ornithologist, and was confirmed by entomologists in our party (K. S. Brown, Jr.; Mohamed Habib). Fruit, by contrast. comes from large and resistant organisms, which do not become unavailable in such brief fluctuations as a cold wave (or do so only after the wave has passed. Observations in central São Paulo state and in Iguaçú National Park after the cold wave indicated that many trees lost leaves, and that a few were killed).

In terms of avifaunas, the difficulties of insectivores in extreme weather are significant because a large group of suboscines, the furnarioid suboscines (families Formicariidae, Furnariidae, Dendrocolaptidae), are essentially insectivorous (Appendix). Tyrannoid suboscines (Cotingidae, Pipridae, Tyrannidae) and oscines (Hirundinidae and following families in the appendix), by contrast, are mostly omnivores, rummage in protected places for food, or can migrate in unfavorable periods. In general, furnarioid suboscines dominate in tall Amazonian forests and tyrannoids and oscines take over in any slightly lower vegetation peripherally (Table 3 compares passerines of a forest near Manaus with forests near Tangará and with a forest even further south, in São Paulo) -- whether the low vegetation is due to seasonal flooding (várzeas), droughts (caatingas, desert scrubs), cold (subtropical forests), humans (capoeira; Novaes, 1973), or other reasons. The Cotingidae and Pipridae. which are primarily fruit eaters, also occur in good numbers in or near the edges of tall Amazonian forests, as do many fruit-eating nonpasseriform birds (Tinamidae, Cracidae, Psittacidae, etc.). It seems that, under the relatively constant conditions of central Amazonia, specialists either on insects (furnarioid suboscines) or fruits (birds in the last sentence) are favored. Slightly further peripherally, occasional cold waves or other "disasters" increasingly make specialized insectivores vulnerable, and they are replaced by generalized omnivores that can switch back and forth between insects and fruit.

The contrast between central and peripheral Amazonian distributions of furnarioid suboscines and other passeriforms thus is likely to have at least one ecological basis, that of occasional disasters which cause difficulties for insectivores. Table 4 compares numbers of species of insectivores, omnivores, and frugivores near Manaus $\left(3^{\circ} \mathrm{S}\right)$, Tangará $\left(15^{\circ} \mathrm{S}\right)$, and in São Paulo $\left(23^{\circ} \mathrm{S}\right)$, showing the lower percentage of species of pure insectivores near Tangará. Some individual insectivores may be killed outright, at least in regions where cold waves or other disasters are more frequent and stronger than at Tanga-

TABLE 3

Percentages of Species of Passerine Birds in Foresta

\begin{tabular}{lcccc}
\hline & Furnarioids (\%) & Tyrannoids & Oscines & Total n. species \\
1. Manausb: Reserva Ducke & 41 & 35 & 24 & 130 \\
2. Tangará Region & 34 & 33 & 33 & 149 \\
3. Barreiro Ricoc & 33 & 37 & 30 & 82 \\
\hline
\end{tabular}

\footnotetext{
a. Eucludes Corvidoe, Hirundinidoe flying over or near forests, as well as nonforest species cosually at forest edges.

b. From Willis, ms; migrants and nonforest species excluded.

c. Fazenda near Anhembi (Sấo Paulo State); currently under study; migrants excluded.
} 
rá da Serra. Others may have difficulties reproducing in short disaster-free periods available in some years (see Willis, 1974). Fruit and insect eaters, however, are more likely to survive brief cold waves, or can use fruits for adults while feeding insects to nestlings, thus increasing the number of young they can produce in short nesting seasons. Fruit eaters also have the advantage of greater mobility, allowing movements to better sites, than do the generally territorial or semiterritorial insectivores. However, fruit eaters have to turn to insects, or move about, in "hard times" for fruits (Morton, 1973).

One finds a rise in insectivorous specics rather than a continued decrease as one goes even further from tall Amazonian forests, into the "ring" of habitats beyond the "peritropical ring". (The data from São Paulo in Tables 3 and 4 provide an example). Furnariidae and Parulidae, plus a number of insectivorous Tyrannidae, occur out in wide open or semiopen zones or in temperate-zone forests. The explanation here, as far as my own observations go, seems not so much that fruits are rare (being replaced by seeds) but that many of these bird species are migratory, eat insects in enclosed places, or have other ways of avoiding bad periods, which are so common as to be predictable. Closer to tall Amazonian forests, these species are probabiy at a disadvantage in direct competition with insectivores which specialize and stay on territories (Willis, 1966), in the long periods between disasters or hard times.

Perhaps the constantly favorable "tropical rain forest" has specialized birds, the next unpredictably bad or semiopen "ring" of habitats has generalists, and the constantly unfavorable and more open second "ring" of habitats has specialists again? Local lists of the type here, from a wide variety of places and habitats, might show if this is indeed a rule of wide applicability.

The ornithologist must ask the additional question: why there is a correlation between major groups of passerines and their food types? Was there no selection for fruit-eating furnarioids, which could thus have occupied niches now occupied by tyrannoids and oscines? Why is there no furnarioid or tyrannoid that eats seeds? The oscines that eat seeds mostly live in lower or more open habitats of the "second ring", and hence have not been considered above except in the list of birds of open areas in the region of Tangará da Serra; but they and the suboscines that do not eat seeds add odd distortions to the generally accepted or "conventional" view of evolution of neotropical passerines.

The conventional view is that neotropical suboscines (especially the "ancestral" furnarioids) are primitive forms that have been retreating into tropical forests ever since the Pliocene closure of the Panamanian land bridge allowed oscines to flood south (Amadon, 1973). Some authors (Slud, 1960; Willis, 1966) have indicated doubts about a thecry that requires oscines not to fly over water and that requires extensive flow of species from species-poor habitats (open ones; Central and North America) to species-rich ones (forested; South America), but the oddities of food types raise further doubts. In ecology, major niches

TABLE 4

Percentages of Species of Different Food Types in Forestsa

\begin{tabular}{llcccc}
\hline & Insectivores (\%) & Omnivores & Frugivores & Total n.・ species \\
1. Manausb & 59 & 30 & 11 & 183 \\
2. Tangará & 50 & 40 & 10 & 208 \\
3. Barreiro Ricoc & 54 & 36 & 10 & 115 \\
\hline
\end{tabular}

\footnotetext{
a. Excludes Apodidae, Trochilidae, Corvidae, Hirundinidae, carnivores other than insectivores, and long-distance migrants.

b. From Willis, ms; nonforest species excluded.

c. From unpublished studies in progress summering migrants excluded as are wintering ones.
} 
are rarely left unfilled for long; but the conventional theory seems to require unfilled (by birds) fruit-eating niches prior to tyrannoid appearance, plus unfilled seed-eating niches until the Pliocene.

I would like to suggest an alternative possibility for evolution of major groups of neotropical passerines: that suboscines that took to eating insects in closed nectropical habitats became furnarioids, related birds that earlier took to fruit-insect use in lower vegetation (in both New and Old World) became various suboscines, including tyrannoids, while those early passerines that took to various types of feeding (including seed eating) in open areas became oscines. To use open habitats, a complex song and hence complex syringeal musculature are advantageous (Morton, 1975). It is possible that, in intermediate habitats, the variably simple to intermediate syringes of tyrannoids are sufficient; and that in closed habitats, the peculiar "tracheophone" syringes of furnarioids produce greater volume even if less modulation. Migrations, pointed or nine-primaried wings, and many other open-country adaptations of oscines are not necessarily advances over furnarioides; just necessary given an open-country environment for oscines.

The alternative view would suggest that oscines were present long ago in the New World, and that their competition prevented development of seed-eating suboscines there as in the Old World. Separation of oscines by continental drift in late Cretaceous or entry into South America by waif dispersal by the Oligocene are possible, since Primates and rodents somehow got to South America by the Oligocene (Simpson, 1969), and since Brodkorb (1960) suggests that seeds led to bird evolution in the Miocene. New World seedeaters (Fringillidae sensu lato, including Emberizinae and Cardinalinae) could have reinvaded the Old World, explaining why there are two main groups of seedeating Oscines (Fringillidae; and Ploceidae of the Old World). The nearest relatives of Fringillidae are nine-primaried tanagers and other New-World birds, and I think it more likely that Fringillidae have moved recently into the Old World than that they have moved recently into the New. Reversing the direction of fringillid (and hence nine-primaried oscine) movement almost eliminates the supposed recent movement of oscines into the neotropics. Wrens, mimids, thrushes, and jays are small groups that may have moved in after closure of land bridges in the Pliocene, as suggested by Amadon.

I agree with Keast (1972) that there was probably not much movement inte South America prior to the Pliocene, thus leaving nine-primaried oscines and suboscines (especially tyrannoids) free to radiate; but suggest that one entrance early led to the huge nine-primaried radiation.

Cracraft (1973) follows Keast and earlier authors (Mayr, 1964) in suggesting that nine-primaried oscines arose in tropical North America, or that the most primitive ones (vireos, warblers) did so, even though most groups are South American. Considering that (a) South America is likely to have been southeast of North America throughout the Cenozoic; (b) nine-primaried passerines are adapted for long-distance flights (Averill, 1925) it seems likely that (c) some migrating nine-primaried birds would have flown over water to or from South America and radiated southward almost as quickly as they did northward. Thus, evolution of nine-primaried oscines in North America until the Pliocene, followed by their flooding southward, still seems unlikely. A northward direction of dispersal, from South to North America, is less likely because fewer southern forms migrate well northward. However, survival of certain primitive migratory nine-primaried oscines mainly in North America could have resulted from relative lack of competition from suboscines, rather than from radiation there. Cox (1968) has suggested that these migrants are mainly ones that were interspecifically outcompeted toward the equator; if so, the drift of continents raises anew the "southern ancestral home" theory in an ecological version for these migrants, with the twist that they would have been avoiding a highly developed and competitive avifauna by migrating northward across the Panamá gap. 
It does not seem likely, under either the conventional or alternate views, that nine-primaried and other oscines originated separately in Old and New Worlds. It is true that Sibley (1970) suggests wrens show resemblances to furnariids in egg-white proteins. It also is interesting that the clambering behavior and plush crown of the oscine Catablyrhynchus diadematus suggest the furnariid Metopothryx aurantiacus, while the clambering furnaıiid Xenerpestes minlosi looks like a leaf clinging Parulid. However, Sibley indicates resemblance of egg-white proteins between nine-primaried oscines and several Old-World groups. These and the similarities of oscine syringes in general (Ames, 1971) throw doubt on separate origin of nine-primaried oscines from local suboscines; it seems more likely that oscines had a common origin and were separated by continental drift or immigrated early to South America.

Under both the conventional and alternative view, suboscines have been unsuccessful in the Old World. Whether they were ever common there is not clear; but the presence of Eurylaimidae in Africa and Asia and of Philepittidae in Madagascar indicates that suboscines evolved before continental drift. The small size and historical vagaries of Old-World tropical forests could have given the advantage to forest-edge oscines over forest-living suboscines. The absence of furnarioids from the Old World, however, indicates that this group may well have evolved in the New World after Africa separated from South America, perhaps from tyrannoid ancestors (Sibley, 1970, doubts that Old-World suboscines are tyrannoids; if he is right, tyrannoids and furnarioids could both postdate drift).

The ancient or pre-continental drift nature of oscines is possible but uncertain under both the alternative and conventional views. Oscines occur on Madagascar, in Australia, and in New Zealarid, three areas much more isolated than is South America. Some could have wandered from nearby continents, for open country oscines are usually good fliers and cross water gaps easily; but others in each region seem primitive (as the lyrebirds of Australia and the Acanthisittidae of New Zealand), suggesting derivatives of oscines present before continental drift. Absence of suboscines in New Zealand and Australia could be due to their extinction or failure to reach adversely open environments there. rather than an indication that suboscines arose after separation of Australia.

Oscines seem unlikely to have descended from birds presently called "suboscines", which have a bony stapes different from that of other Aves and from Reptilia (Feduccia, 1974, 1976). "Suboscines", with their variable syringes (Ames, 1971) could easily have descended from primitive oscines, before or as the latter developed their complex syringes. Possibly, to avoid confusion, the "suboscines" with the modified stapes should in future works be given a noncommittal name like "paraoscines", reserving the name "suboscines" for fossil early passerines of simple syringes and primitive stapes.

\section{ACKNOWLEDGEMENTS}

I appreciate the support of the Universidade Estadual de Campinas for the expedition and the aid of other members of the group. especially Keith S. Brown, Jr.. W. Benson, K. Brown, D. Pearson, E. Eisenmann and Yoshika Oniki helped with the manuscript.

\section{SUMÁrIo}

As aves das matas do rio Sopotuba, Mato Grosso, foram estudadas durante uma "friagem" no mês de julho de 1975. As aves insetívoras foram menos conspícuas e as aves frugivoras mais conspicuas durante a "friagem". E possivel que em "desastres" ocasionais como a "friagem", nas margens de florestas tropicais, haja seleção contra aves insetívo. ras e seleção favorecendo as aves "onivoras", isto é, que comem insetos e frutas. A tendência para sa ter menos Passeriformes "suboscines" nas margens de florestas neotropicais parece ser devido à falta de suboscines do grupo de "furnarioides", que são insetívoros. As teorias de que os suboscines são ancestrais de "oscines", e que os oscines entraram na América do Sul no Plioceno, parecem improváveis, pois se assim fosse, teria faltado oscines comendo sementes por várias épocas geológicas. 


\section{LITERATURE CITED}

AMAdon, D.

1973 - Birds of the Congo and Amazon forests: a comparison. pp. 267-277. In Meggers. B.J., E.S. Ayensu, and W.D. Duckworth, Tropical Forest Ecosystems in Africa and South America: a Comparative Review. Smithsonian Inst. Press, Washington.

AMES, P.L.

1971 - The morphology of the syrinx in passerine birds. Bull. Peabody Mus. Nat. Hist., 32

AVERILL, C.K.

1925 - The outer primary in relation to migration in the tenprimaried oscines. Auk, $42: 353-358$.

BATES, H.W

1962 - The naturalist on the River Amazons. Univ. Calif. Press, Berkeley. $469 \mathrm{pp}$.

BRODKORB, P.

1960 - How many species of birds have existed? Bull. Florida State Mus., Biol. Sci., 5: 41 -5̄3.

BRoWN JR., K.S.

1972 - Maximizing daily butterfly counts. J. Lepidopterists Soc., 26:183-196

Cox, G.W.

1968 - The role of competition in the evolution of migration. Evolution, 22:180-192.

Cracraft, J.

1973 - Continental drift, paleoclimatology, and the evolution and biogeography of birds. J. Zool. Lond. $169: 455-545$.

Feduccia, A,

1974 - Morphology of the bony stapes in New and OId World suboscines: new evidence for common ancestry. Auk, 91: 427-429.

1976 - Morphology of the bony stapes in the Meruridae and Acanthisittidae: evidence for oscine affinities. Wils. Bull., 87 : 418-420.

HAFFER, J.

1969 - Speciation in Amazonian forest birds. Science, $165: 131137$.

1974 - Avian speciation in tropical South Ame rica. Publ. Nuttall Ornith. Club, n. ${ }^{\circ} 14$.

HAVERSCHMIDT, F.

1968 - Birds of Surinam. Oliver and Boyd, Edinburgh. $445 \mathrm{pp}$.

1975 - The occurrence and the habitat of the Pale-bellied Mourner Rhytipterna immunda in Surinam. Bull. B. O. C., $95: 140-141$.

KEAST, A.

1972 - Ecological opportunities and dominant families, as illustrated by the neotropical Tyrannidae (Aves). pp. 229-277. In
Dobzhansky, T., M.K. Hecht, and W. C. Steere, Evolutionary Biology, vol. 5. Appleton-Century-Crofts, N. Y.

LISBÔA, F.L.

1975 - Estudos sobre a vegetação das campinas Ainazônicas - II. Observaçōes gerais e revisão bibliográfica sobre as campinas Amazônicas de areia branca. Acta Amazonica, $5: 211-223$.

MAYR, E.

1964 - Inferences concerning the Tertiary American bird faunas. Proc. Nat. Acad. Sci., USA, $51: 280-288$.

MEYER DE SCHAUENSEE, $R$.

1970 - A guide to the birds of South America. Livingston Publ. Co., Wynnewood, Pa. $470 \mathrm{pp}$.

MORTON, E.S.

1973 - On the evolutionary advantages and disadvantages of fruit eating in tropical birds. Amer. Natur., 107: 8-22

1975 - Ecological sources of selection on avian sounds. Amer. Nat., $109: 17-34$.

NAUMBurg, E.M.B.

1930 - The birds of Mato Grosso, Brazil. Bull. Amer. Mus. Nat. Hist., $60: 432 \mathrm{pp}$

Novaes, F.C.

1973 - Aves de uma vegetação secundária na fóz do Amazonas. Publ. Avulsas Museu Goeldi, Belém, $21: 1-88$.

PELZELN, A. VON,

1867-1871 - Zur Ornithologie Brasiliens. Resultate von Johann Natterers Reisen in den Jähren 1817 bis 1835. A. Pichlers Witwe and Sohn, Wien.

Simpson, G.G.

1969 - South American mammals. pp. 879-909 in Fittkau, E.J., J. Illies, H Klinge, G.H. Schwabe, and H. Sioli, eds., Biogeography and Ecology in South America, vol. 2, W. Junk Publ., The Hague.

SiBLEy, C.G.

1970 - A comparative study of the egg-white proteins of passerine birds. Bull. Peabody Mus. Nat. Hist., $32: 131$ pp. and 38 plates.

SLun, $\mathrm{P}$,

1960 - The birds of Finca "La Selva". Costa Rica: a tropical wet forest locality. Bull. Am. Mus. Nat. Hist., $121: 49-148$.

WILLIS, E.O.

1966 - The role of migrant birds at swarms of army antes. Living Bird, 5 : 187-232.

1969 - On the behavior of five species of Rhegmatorhina, ant-following antbirds of the Amazon basin. Wilson Bull., $81: 363-395$.

1974 - Populations and local extinctions of birds on Barro Colorado Island, Panamá. Ecol. Monog., 44 : 153-169. 


\section{APPENDIX}

Birds Observed in Forests, Western Mato Grosso*

Number of Individuals on Given Day (July, 1975)

Day:

Hours Afield:

Tinamidae (B.)

Tinamus tao

Crypturellus soui strigulosus tataupa

Ardeidae (E.)

Pilherodius plleatus

Cathartidae (E.)

Cathartes sp.

Coragyps atratus

Sarcoramphus papa

Accipitridae (E.)

Elanoides forficatus

Buteo magnirostris

Leucopternis albicollis

Spizaetus ornatus

tyrannus

Geranospiza caerulescens

Falconidae (E.)

Daptrius americanus (D.)

Micrastur ruficollis (?)

Falco rufigularis

Phasianidae (B.)

Odontophorus gujanensis

Cracidae (B.)

Penelope sp.

Crax or Mitu sp.

Rallidae (D.)

Aramides cajanea

$\begin{array}{lllllll}11 & 12 & 13 & 14 & 15 & 16 & 17 \\ 6.2 & 7.5 & 11.5 & 9.3 & 11.8 & 11.3 & 11 . \\ & & & & & & \\ & & 5 & 2 & 5 & 1 & 3 \\ 6 & 10 & 5 & 5 & 6 & 2 & 1 \\ 2 & & 5 & 2 & 2 & & \\ 5 & & 5 & 2 & 2 & & \end{array}$

$\begin{array}{lll}1 & 1 & \\ & 1 & 1\end{array}$

$\begin{array}{lll}3 & 2 & 6\end{array}$
21

$\begin{array}{llll}6.2 & 11.0 & 9.8 & 5.5\end{array}$

$\begin{array}{lll}5 & 4 & 2\end{array}$

$1 \quad 3 \quad 1$

11

1

2

2

10

2

3

Eurypygidae (D.)

Eurypyga helias

Columbidae (B.)

Columba speciosa cayennensis plumbea

Claravis pretiosa

Leptotila rufaxilla

Psittacidae (B.)

Ara chloroptera

manilata

nobilis

$\begin{array}{rrrrrrrrr} & 2 & & & & 3 & 4 & 4 & \\ & & & 3 & & 3 & 5 & & 15 \\ & 15 & 30 & 30 & 5 & 30 & 35 & 75 & 55\end{array}$

Effects of a cold wave... 
Day:

Aratinga leucophthalmus waddellii

Brotogeris versicolurus

Pionus menstruus

Amazona amazonica farinosa

Cuculidae (D.)

Piaya cayana minuta

Strigidae (D.)

Otus cf. watsonii

Pulsatrix perspicillata (E)

Glaucidium brasilianum (?)

Caprimulgidae (D.)

Nyctidromus albicollis

Nyctiphrynus ocellatus

Apodidae (D.)

Chaetura egregia (?)

Reinarda squamata

Trochilidae (A.)

Glaucis hirsuta

Phaethornis hispidus ruber

Campylopterus largipennis

Eupetomena macroura

Florisuga mellivora

Anthracothorax nigricollis

Lophornis magnifica (?)

Thalurania furcata

Hylocharis cyanus chrysura

Amazilia fimbriata

Heliomaster furcifer

Trogonidae (C.)

Trogon rufus

collaris

violaceus

curucui

Momotidae (C.)

Momotus momota

Galbulidae (D.)

Brachygalba lugubris

Galbula ruficauda leucogastra

Bucconidae (D.)

Notharchus macrorhynchus tectus

Bucco tamatia

\section{APPENDIX (cont.)}

$\begin{array}{rrrrrrrrrrr}11 & 12 & 13 & 14 & 15 & 16 & 17 & 18 & 19 & 20 & 21 \\ & & 6 & 10 & 30 & 500 & 20 & & 30 & 20 & \\ 10 & 50 & 5 & 8 & & & & 6 & 20 & 15 & 15 \\ & 5 & & & & & & 5 & & & \\ 15 & 50 & 10 & 20 & 10 & 10 & 5 & & 15 & 30 & 15 \\ 4 & 15 & & & & & & & & & 5 \\ 4 & 6 & 15 & 15 & 5 & 5 & 2 & 4 & 10 & 10 & 15\end{array}$

1

4

$\begin{array}{lllllll}1 & 1 & 2 & 2 & 1 & & \\ & 5 & 4 & 6 & & & \\ & & & & & 1 & 1\end{array}$

$\begin{array}{llllllll}1 & 2 & 1 & 10 & & & 1 \\ 1 & & & & 1 & & \\ 1 & & 4 & 5 & 4 & 4 & 1 \\ 1 & & & & & 1\end{array}$

1

4
5

121

1

6 
APPENDIX (cont.)

Day:

Nystalus striolatus

Monasa nigrifrons morphoeus

Chelidoptera tenebrosa

Nonnula ruficapilla

Capitonidae (C.)

Capito dayi

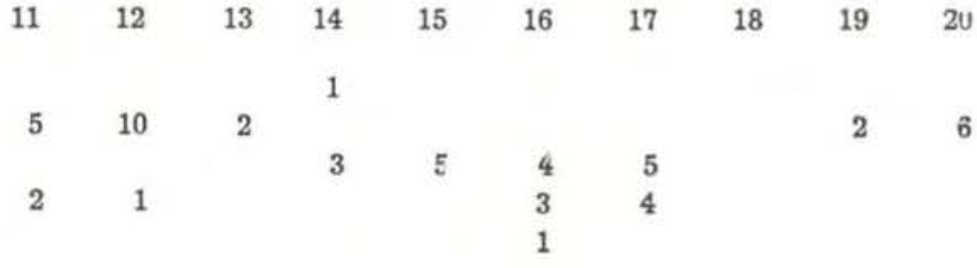

Ramphastidae (C.)

Pteroglossus castanotis inscriptus bitorquatus

Selenidera maculirostris

Ramphastos culminatus cuvieri

Picidae (D.)

Picumnus cf. aurifrons

Piculus leucolaemus

Celeus torquatus

Melanerpes cruentatus (C.)

Veniliornis affinis

Phloeoceastes rubricollis

Dendrocolaptidae (D.)

Dendrocincla fuliginosa merula

Sittasomus griseicapillus

Glyphorchynchus spirurus

Hylexetastes perrotii

Dendrocolaptes hoffmannsi

$\begin{array}{lllllllllll}5 & 10 & 5 & 6 & 2 & 1 & & & & 4 & \\ & & 4 & 2 & & & & & & 2 & \\ 2 & 2 & 4 & 6 & 1 & 1 & & & & & \\ 4 & 4 & 6 & 5 & 5 & 5 & 2 & 2 & 6 & 5 & 2\end{array}$

Xiphorhynchus picus elegans guttatus

Lepidocolaptes albolineatus

Campyloramphus trochilirostris

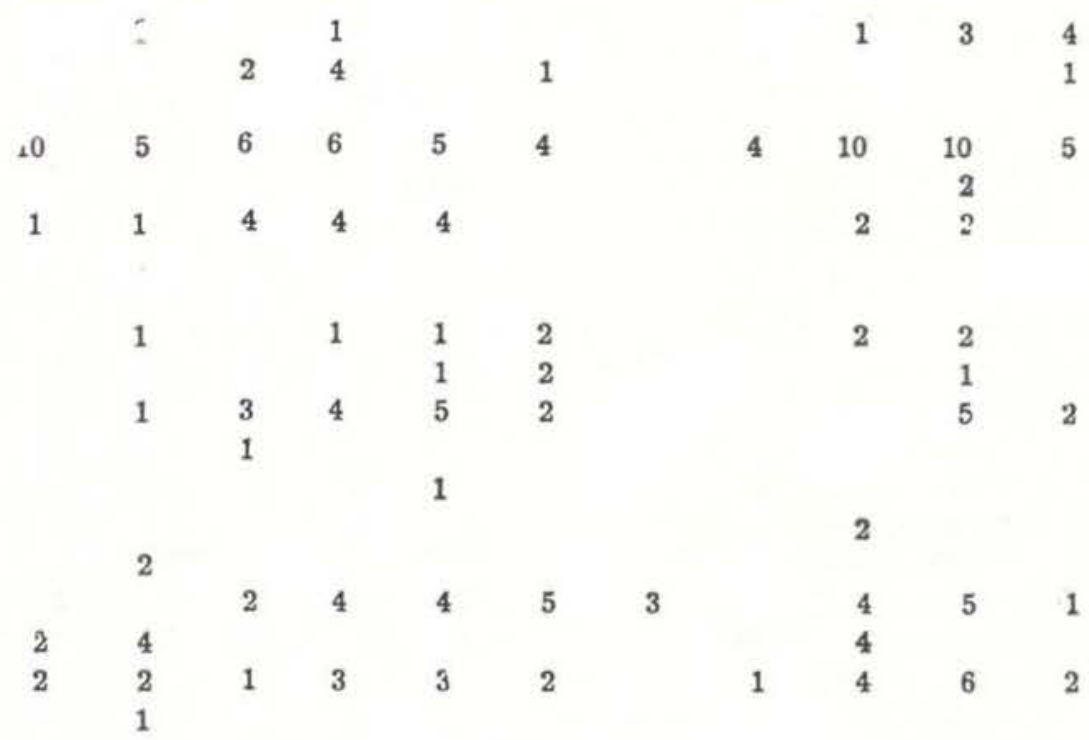

Furnarlidae (D.)

Synallaxis rutilans

11

$2 \quad 2$

$2 \quad 2$

Philydor erythrocercus erythropterus

Automolus ochrolaemus

Xenops rutilans minutus

12

Formicariidae (D.)

Cymbilaimus lineatus

Thamnophilus palliatus aethiops schistaceus punctatus

doliatus amazonicus

Dysithamnus mentalis

Thamnomanes caesius

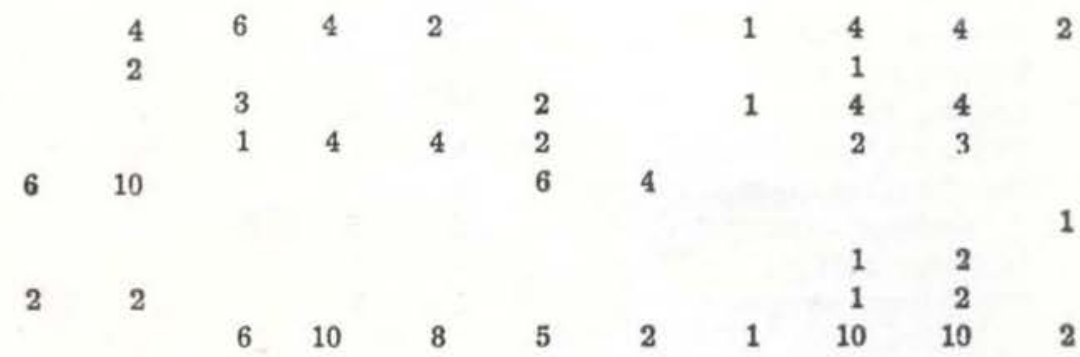

Effects of a cold wave... 
APPENDIX (cont.)

Day:

Myrmotherula brachyura hauxwelli

ornata

axillaris

menetriesii

Herpsilochmus longirostris rufimarginatus

Microrhopias quixensis

Formicivora grisea

Drymophila devillei

Cercomacra cinerascens

Pyriglena leuconota

Myrmoborus leucophrys myotherinus

Hypocnemis cantator

Hypocnemioides maculicauda

Myrmeciza hemimelaena atrothorax

Rhegmatorhina hoffmannsi

Hylophylax poecilonota

Phlegopsis nigromaculata

Formicarius analis

Cotingidae (C.)

Xipholena punicea

Lipaugus vociferans

Pachyramphus polychopterus (D) marginatus (D)

Platypsaris minor (D.)

Tityra cayana semifasciata inquisitor

Gymnoderus foetidus haematonota (?) nigrescens

$\begin{array}{llll}11 & 12 & 13 & 14\end{array}$

2

2

11

$\begin{array}{llr}4 & 6 & 2\end{array}$

6

4

$5 \quad 8 \quad 10$

$\begin{array}{lll}10 & 5 & 3\end{array}$

10

$\begin{array}{rrrrrrrrrrr}3 & & & 4 & & & & & & & \\ 1 & & 10 & 20 & 15 & 15 & 5 & & 15 & 5 \\ & 6 & 10 & 20 & 10 & 15 & 5 & 6 & 10 & 15 & 5 \\ & 1 & & & & & & & & & \\ 1 & & & 1 & & 2 & & & & \\ & 10 & & & 5 & 5 & 5 & 2 & & & \\ & & & & 3 & & & & 2 & & \\ & & 1 & & 5 & 2 & & & & 2 \\ & & 1 & 2 & & & & & 5 & 6\end{array}$

18

Pipra rubrocapilla

nattereri

fasciicauda

Manacus manacus

Heterocercus linteatus

Neopelma pallescens

Tyranneutes stolzmanni

Piprites chloris

Schiffornis turdinus

Tyrannidae (C.)

Sirystes sibilator

Tyrannopsis sulphurea

Legatus leucophaius

Megarhynchus pitangua

Myiodynastes maculatus

Myiozetetes cayanensis

Casiornis rufa

Rhytipterna simplex immunda $\begin{array}{lllll}10 & 5 & 2 & 2 & 6\end{array}$

1

3

$\begin{array}{lllll}4 & 2 & 1 & 4 & 1\end{array}$

$\begin{array}{rrrrrrr}1 & 5 & 10 & 10 & 10 & 5 & 4 \\ & & & & & & 2\end{array}$

$6 \quad 15 \quad 2$

14 
APPENDIX (cont.)

Day:

\begin{tabular}{|c|c|c|c|c|c|c|c|c|c|}
\hline 11 & 12 & 13 & 14 & 15 & 16 & 17 & 18 & 19 & 20 \\
\hline \multirow[t]{2}{*}{3} & 3 & & & & & & & & \\
\hline & & & 1 & & & & & 4 & 2 \\
\hline & 1 & 2 & 4 & 2 & 2 & & 3 & 5 & 4 \\
\hline & & & 2 & & & & & 2 & 2 \\
\hline & 1 & & & & & & & & \\
\hline & & & & & & 4 & & & 4 \\
\hline & 2 & 5 & 5 & 4 & 2 & 2 & 4 & & 4 \\
\hline & & & & & 2 & & & & \\
\hline & & & 1 & & & & & & \\
\hline & & 1 & & & & & & & \\
\hline & 5 & 10 & 10 & 6 & 5 & & & 5 & 6 \\
\hline & & & & & & & & & 2 \\
\hline & 3 & 4 & & & & & & & 5 \\
\hline & & & & & 4 & 2 & & & \\
\hline \multirow[t]{5}{*}{5} & 10 & 15 & 15 & 10 & 10 & 5 & & 8 & 20 \\
\hline & 3 & & & & & & & & \\
\hline & 2 & & & & & & & & \\
\hline & & & & & & & 2 & 1 & 5 \\
\hline & & & & & & & & & 2 \\
\hline
\end{tabular}

Myiarchus ferox

tyrannulus

tuberculifer (D.)

Empidonax euleri (D.)

Cnemotriccus fuscatus (D.)

Terenotriccus erythrurus (D.)

Hirundinea ferruginea (D.)

Tolmomyias sulphurescens flaviventris

Ramphotrigon ruficauda (D.)

Todirostrum sp. (D.)

Idioptilon zosterops (D.)

Myiornis ecaudatus (D.)

Elaenia parvirostris (?) cristata (?)

Myiopagis gaimardii caniceps

Camptostoma obsoletum

Serpophaga inornata (?)

sp. (tyrannulet)

Pipromorpha oleaginea

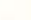

Hirundinidae (D.)

Progne chalybea

Stelgidopteryx rufipennis

Corvidae (C.)

Cyanocorax chrysops cristatellus

1

Troglodytidae (D.)

Campylorhynchus turdinus

Odontorchilus cinereus

Thryothorus genibarbis

Microscerculus marginatus

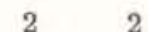

$\begin{array}{llllllllllll}2 & 2 & & & 1 & & & & 4 & 2 \\ 6 & 2 & 4 & 6 & 4 & 4 & 2 & 4 & 8 & 4 & 6 \\ & 6 & & & & & & & 1 & \end{array}$

Turdidae (C.)

Turdus ef. amaurochalinus fumigatus albicollis

$\begin{array}{llllllll}4 & 2 & 5 & 7 & 6 & 5 & 5 \\ & & & & & 3 & 2\end{array}$

Sylviidae (D.)

Ramphocaenus melanurus

Vireonidae (C.)

Cyclarhis gujanensis (D.)

Vireo olivaceus

Hylophilus pectoralis (?) muscicapinus (D.)

Icteridae (C.)

Gymnostinops yuracares

Cacicus cela

Icterus cayanensis

$\begin{array}{rrrrrrrrrr} & & 5 & 2 & 2 & 2 & & & 1 & 2 \\ 1 & 5 & 2 & 3 & 2 & 1 & & 5 & 5 & 8 \\ 1 & 4 & 5 & 10 & 15 & 5 & 1 & 5 & 20 & 4\end{array}$

Effects of a cold wave.. 
APPENDIX (cont.)

Day:

11

13

14

15

16

$\begin{array}{ll}17 & 18\end{array}$

19

20

21

Parulidae (D.)

Parula pitiayumi

Granatellus pelzelni

Basileuterus riaveolus culicivorus rivularis

$\begin{array}{lllllll} & & & & & 1 & \\ & & & & 1 & & \\ & 4 & 10 & 6 & 2 & 4 & 3\end{array}$

Coerebidae (C.)

Coereba flaveola

Cyanerpes caeruleus cyaneus

Chlorophanes spiza

Dachis cayana

lineata

$\begin{array}{rrrrrrrrr} & 3 & 2 & 5 & 2 & & 4 & 3 & 2 \\ & & & & 2 & & & & \\ & & & & 4 & & 2 & 1 & \\ 2 & 3 & 2 & 4 & 2 & 1 & 2 & 2 & \\ & 6 & 5 & 5 & 5 & & 2 & 10 & \end{array}$

Tersinidae (C.)

Tersina viridis

Thraupidae (C.)

Euphonia laniirostris rufiventris

Tangara chilensis cyanicollis

nigrocincta mexicana

gyrola

cayana

Thraupis sayaca palmarum

Ramphocelus carbo

Lanio versicolor (D.)

Tachyphonus cristatus luctuosus

Eucometis penicillata

Nemosia pileata

Hemithraupis flavicollis

Cissopis leveriana

Fringillidae (C.)

Saltator maximus

Pitylus grossus

Cyanocompsa cyanoides

Arremon taciturnus (D.)

610

$10-2$

4

$\begin{array}{llll}1 & 2 & 4\end{array}$

$\begin{array}{llllll}5 & 4 & 4 & 4 & 2\end{array}$

2

1

$\begin{array}{llll} & & 5 & 2 \\ 2 & 2 & 4 & 2\end{array}$

10

$42 \quad 2 \quad 1$

$\begin{array}{lllllllll}6 & 2 & 2 & 3 & 5 & 10 & 4\end{array}$

$\begin{array}{rrrrrrrrrrr}1 & 1 & 1 & 5 & 6 & 2 & 2 & 1 & 4 & 5 & 2\end{array}$

1

$\begin{array}{rrrr} & 5 & 10 & 5 \\ & 4 & 2 & 2 \\ & 3 & 3 & \\ & & & 1\end{array}$

1 